Current Trends within Sustainability Accounting Research: ...

Prof. Hamdy Mahmoud Kadous \& Dr. Heba Shaker Fathy Elbably

\title{
Current Trends within Sustainability Accounting Research: A Critical Literature Review
}

\author{
Professor \\ Hamdy Mahmoud Kadous \\ Professor of Financial \\ Accounting \\ Helwan University
}

\author{
Heba Shaker Fathy Elbably \\ Assistant Lecturer \\ Accounting Department \\ Helwan University
}

\section{Abstract:}

This paper aims to address and assess the efforts of different scholars regarding the Current significance of Sustainability Accounting and its financial impacts through assessing the academic literature. The main goal of this study is to offer insights into the current state of Sustainability Accounting Research. This study summarizes the accounting literature in Sustainability Accounting areas and evaluates accounting researchers' efforts in suggesting solutions to face specific challenges. The researcher provides a literature review of the current trends within this area in a concise and harmonized manner for a broader audience in academia and practice. The study found that given the importance of sustainability accounting for both current and future generations, the accounting literature revealed considerable attention towards the issues of sustainability and the roles it plays in legitimating 
Current Trends within Sustainability Accounting Research: ...

Prof. Hamdy Mahmoud Kadous \& Dr. Heba Shaker Fathy Elbably

business claimed belief in the sustainability of business operations. Also, Sustainability Accounting has more opportunities for growth. This study can be considered one of the few Egyptian theoretically based studies to evaluate the efforts of different scholars regarding sustainability accounting both in Egypt and Worldwide. Its conclusions, therefore, serve as a foundational basis for further empirical and theoretical examination.

Keywords: Sustainability Accounting, Corporate Social Responsibility (CSR), Stakeholders, Shareholders, Financial Performance, Financial position, Firm value, USA, Egypt.

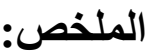

تهدف هذه الورقة إلى تناول وتقييم جهود الباحثين المختلفه فيما يتعلق بالأهميـة الحاليـة

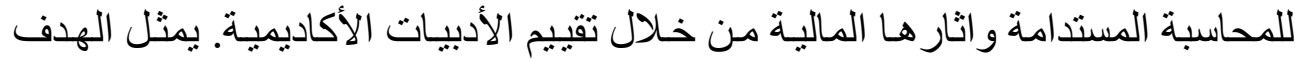
الرئيسي من هذه الدر اسة تقديم نظرة ثاقبة للوضع الحالي لبحوث المحاسبة المستدامة.

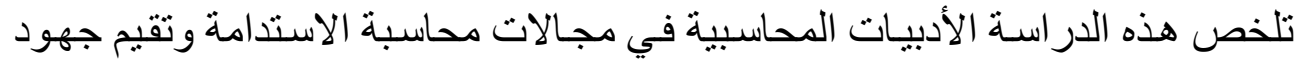
باحثي المحاسبة في اقتر اح حلول لمواجهة بعض التحديات. تقدم الباحثه مر اجعة أدبيـة

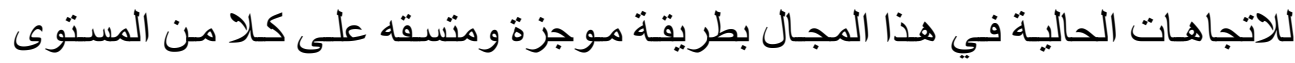

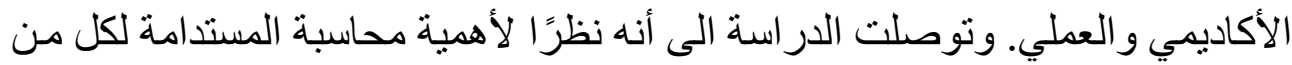

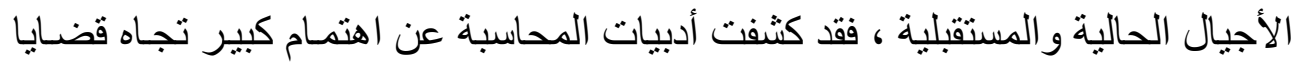

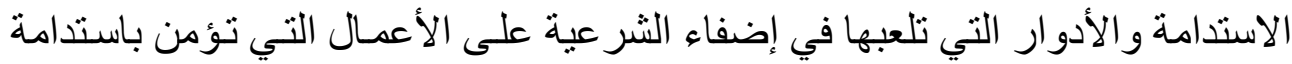

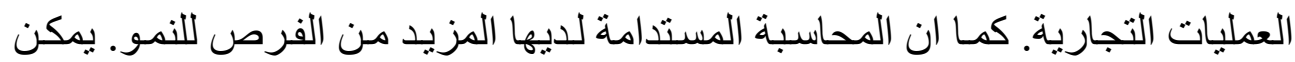

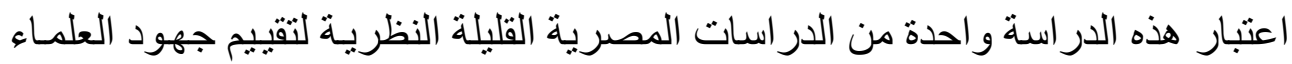


Current Trends within Sustainability Accounting Research: ...

Prof. Hamdy Mahmoud Kadous \& Dr. Heba Shaker Fathy Elbably

المختلفين فيما يتعلق بالمحاسبة المستدامة في كل من مصر و العـالم. وبالتالي ، فـان النتائج تعتبر بمثابة أساس لمزيد من الفحص التجريبي والنية النظري.

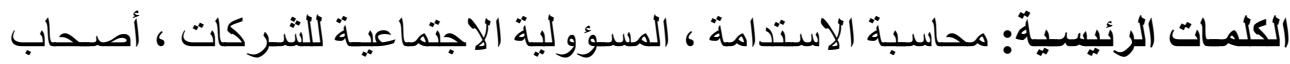

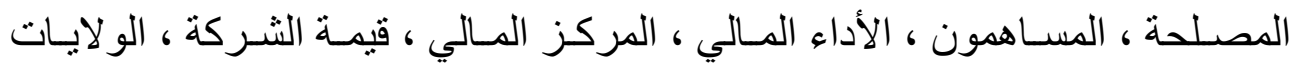
المتحدة الأمريكية ، مصر، المعرن

\section{Introduction:}

Several studies have examined research and practice in Sustainability Accounting and Reporting, in Egypt and worldwide. These studies examined the research and practice from different viewpoints. Therefore, the researcher categorizes past research according to the problem addressed by classifying the paper into six sections as follows:

\section{Studies directly related to Sustainability accounting and its consequences:}

Various research studies have been conducted in the context of sustainability accounting and reporting and its consequences during the last two decades. This section will display some of those studies that have been conducted during the period that started from 2010 till 2019.

In 2010, Burritt \& Schaltegger aimed to discuss the future focus of sustainability accounting in research and practice. They illustrated the main arguments and issues discussed in two main paths relating to the development of sustainability accounting. 
Current Trends within Sustainability Accounting Research: ...

Prof. Hamdy Mahmoud Kadous \& Dr. Heba Shaker Fathy Elbably

The first is the critical path that considers sustainability accounting as a source of the problems that lead to unsustainable development and for which an awakening or awareness of this issue is the main focus of attention. Path 2 is the managerial path which views sustainability accounting as the provider of solutions to problems and directs attention to tools which can support decisions to be made in a set of diverse circumstances by diverse actors, different types of managers as well as different stakeholders. Through the assessment of recent literature, Burritt \& Schaltegger concluded that both paths need to be followed if sustainability is to become more than an awareness-building exercise (critical path) and to move into problem-solving (Managerial path). They also stated that it is necessary to emphasize more on promoting management decision making through the development of sustainability accounting and reporting (Burritt \& Schaltegger, 2010).

To support their paper recommendations, Schaltegger, \& Burritt conducted their second paper under the title of "Sustainability accounting for companies: Catchphrase or decision support for business leaders?". Their fundamental focus was on the role of sustainability accounting as an approach to assist management in improving corporate sustainability and responsibility. They reviewed the literature on sustainability accounting from an information management perspective and differentiated different interpretations of sustainability accounting. Finally, they 
Current Trends within Sustainability Accounting Research: ...

Prof. Hamdy Mahmoud Kadous \& Dr. Heba Shaker Fathy Elbably

concluded that; First, there is a significant need for encouraging a diversity of research methods in the direction of sustainability accounting. Second, conducting theoretical research should be on a pragmatic orientation basis to be useful to corporate managers in practice. Third, the relationship between sustainability accounting and sustainability reporting needs to be extended as a practical imperative by moving beyond the procedural tasks designed to maintain report preparation, information verification, and disclosure (Schaltegger, \& Burritt, 2010).

Concerning the application of Sustainability accounting and reporting in the mining industry, Lodhia \& Hess developed a paper in 2014 to provide an understanding of current sustainability accounting and reporting practices in mining through assessing the academic literature. They analyzed the literature in the Journal of Cleaner Production from 2004 to 2013. From the analysis, they concluded that the progress of sustainability accounting and reporting practices is slow. Also, mining companies were not fully disclosing their sustainability impacts, especially in developing country context. Lodhia \& Hess proclaimed that there is a need for effective sustainability management and reliable reporting for mining companies in their transformation to sustainability (Lodhia, \& Hess, 2014).

Concerning the role of accountants, Schaltegger \& Zvezdov developed a study in 2015 to investigate whether accountants are 
Current Trends within Sustainability Accounting Research: ...

Prof. Hamdy Mahmoud Kadous \& Dr. Heba Shaker Fathy Elbably

playing a role in managing sustainability information and, if yes, what their role is. Depending on the responses of 58 corporate practitioners through interviews, this paper explored the role of accountants in the sustainability accounting practices in the UK and Germany's leading companies in the field of sustainability reporting. Second, the researchers analyzed the role of accountants from a power theory perspective. They found that accountants are mainly representing a gate-keeping role between sustainability managers and higher management but partially involved in sustainability accounting practice. The findings highlighted the importance of how to better involve accountants in earlier steps of the sustainability management accounting process (Schaltegger \& Zvezdov, 2015).

In 2016, Khan, Serafeim, \&Yoon carried out one of the most significant empirical studies on US public firms to distinguish between investments in material versus immaterial sustainability issues. They pursed to examine whether firms with good sustainability ratings outperform those with poor ratings. Calendar-time portfolio stock return regressions and firm-level panel regressions partitioned by materiality constructed indexes based on the SASB guidelines are used to present new evidence on the value implications of sustainability investments.

They found that firms with good ratings on material sustainability issues considerably exceed firms with poor ratings. 
Current Trends within Sustainability Accounting Research: ...

Prof. Hamdy Mahmoud Kadous \& Dr. Heba Shaker Fathy Elbably

In contrast, firms with good ratings on immaterial sustainability issues do not exceed firms with poor ratings on the same issues. They suggested that investments in sustainability issues are shareholder-value enhancing (Khan, Serafeim, \&Yoon, 2016).

In Singapore, Loh et al. conducted a study to investigate the relationship between sustainability reporting and firm value in terms of market value based on listed companies in Singapore. Empirical results indicated that sustainability reporting is positively associated with the firm's market value, and the better the quality of sustainability reporting, the stronger the linkage (Loh, Thomas, \& Wang, 2017).

In Nigeria, Nnamani et al. developed a paper to evaluate the effect of sustainability accounting on the financial performance of the Nigerian brewery listed firms. The researchers worked on determining the effect of social responsibility cost on the profitability of the selected firms and identifying the type of the relationship between employees' benefits cost and the firms' financial performance. Empirically, return on asset and return on equity are used as dependent variables, while Total Personal cost to Total Asset (TPCTA) ratio, and Total Equity to Total Asset (TETA) as independent variables. The study reveals that sustainability reporting has a positive and significant impact on the financial performance of firms studied. Following the findings, the study suggests that firms in Nigeria should invest a 
Current Trends within Sustainability Accounting Research: ...

Prof. Hamdy Mahmoud Kadous \& Dr. Heba Shaker Fathy Elbably

reasonable amount of their earnings on sustainability activities. The study recommended the Financial Reporting Council of Nigeria (FRC) to make sustainability reporting mandatory (Nnamani, Onyekwelu, \& Ugwu, 2017).

In Australia, Kaur \& Lodhia aimed to examine how stakeholders are engaged in the sustainability accounting and reporting processes of Australian local councils. They used the Managerial stakeholder theory to provide a theoretical basis for exploring stakeholder engagement in the sustainability accounting and reporting process. They depended on interviews and document analysis to collect data. Besides, they used three Australian local councils as a case study research to explore stakeholder engagement practices. The study's results referred to the significance of engaging stakeholders in the whole sustainability accounting and reporting process, the development of strategic plans and sustainability indicators, the measurement of sustainability performance, and the preparation of sustainability reports (Kaur \& Lodhia, 2018).

In their paper in 2018, Alshehhi et al. displayed a review of different studies related to the impact of corporate sustainability on corporate financial performance. They identified the developing trends and issues that hinder conclusive consensus on that relationship. The study concluded that about $78 \%$ of publications investigating the relationship between corporate 
Current Trends within Sustainability Accounting Research: ...

Prof. Hamdy Mahmoud Kadous \& Dr. Heba Shaker Fathy Elbably

sustainability and financial performance report a positive relationship. It also found that disparate views regarding the relationship are due to variations in research methodology and measurement of variables. Moreover, literature is considering corporate social responsibility (CSR), emphasizing the social dimension of sustainability and ignoring both environmental and economic dimensions instead of considering sustainability as a whole (Alshehhi, Nobanee, \& Khare, 2018).

Other researchers like (Sutopo et al. 2018) examined whether the information provided by companies that receive the Sustainability Reporting Award (SRA) increases the value relevance of the financial statements than those that do not receive (SRA). The researchers used stock price $(\mathrm{P})$ and stock return $(\mathrm{R})$ as dependent variables and Book value per share (BVPS), Earnings per share (EPS), and Earnings per share change (EPSC) as independent variables to investigate the relationship. The study examined the data collected from a sample of 110 winners of SRA (SRA firms) and 110 that did not receive SRA (non-SRA firms) from 2008 to 2016 by running regression models.

Sutopo et al. concluded that there is a positive relationship between EPS and stock price $(\mathrm{P})$, and this positive association is higher for SRA firms than that for the non-SRA firms. Moreover, EPSC is positively associated with $R$, and this positive 
Current Trends within Sustainability Accounting Research: ...

Prof. Hamdy Mahmoud Kadous \& Dr. Heba Shaker Fathy Elbably

relationship is also higher for SRA firms than that for the nonSRA firms. However, this study found that the value relevance of BVPS for SRA firms is lower than for non-SRA firms. Therefore, the study implied that the winners of SRA provide information that contributes to the usefulness of financial statements, mainly the information about EPS and EPSC (Sutopo, Kot, Adiati, \& Ardila, 2018).

Regarding the impact of social, environmental, and corporate governance disclosures (ESG) on firm value, Aboud \& Diab explored this relationship by investigating the Egyptian companies during the period beginning from 2007 and ending in 2016. The study used univariate and multivariate analyses to compare the value of firms listed in the Egyptian Corporate Responsibility ESG index compared to those unlisted ones. Study findings supported the economic benefits of ESG disclosures. It was found that firms listed in the ESG index have higher firm value than unlisted ones. More, there is a positive association between firms' higher rankings in the index and firm value, as measured by Tobin's q (Aboud \& Diab, 2018).

In Egypt, (Almaleeh, 2019) pursed in her study to investigate the association between adopting sustainability practices by Egyptian companies and their level of profitability by testing three main hypotheses. The hypotheses are seeking to examine whether first sustainable firms achieve higher levels of the market value of 
Current Trends within Sustainability Accounting Research: ...

Prof. Hamdy Mahmoud Kadous \& Dr. Heba Shaker Fathy Elbably

equity than non-sustainable firms; second, whether sustainable firms have higher levels of return on equity compared to nonsustainable ones. Third, the value of cash dividends paid by sustainable firms to their stockholders as opposed to nonsustainable ones. The study used the Egyptian companies listed in the Egyptian stock market in 2015 formed of 221 companies to test the hypotheses. The results revealed that sustainability practices are associated with a higher level of both the market value of equity and return on equity. Additionally, the study concluded that sustainable firms paid higher cash dividends to its stockholders (Almaleeh, 2019).

\section{Studies related to Sustainability accounting and its determinants:}

Martínez-Ferrero, Garcia-Sanchez, \& Cuadrado-Ballesteros directed their efforts to analyze the relationship between financial statements quality and the level of disclosure of CSR practices at an international level. They considered CSR information disclosure measured by the level of standardized information in terms of the Global Reporting Initiative (GRI) guidelines as a dependent variable, and the quality of financial reporting measured by (EM practices, Conservative accounting, and accruals quality (AQ)) as independent variables. The researchers used the Tobit method for panel data. The results showed that conservative companies, with a high level of accruals quality and 
Current Trends within Sustainability Accounting Research: ...

Prof. Hamdy Mahmoud Kadous \& Dr. Heba Shaker Fathy Elbably

those that carry out earnings management practices to a lesser extent, report high-quality financial information and high-quality CSR information (Martínez-Ferrero, Garcia-Sanchez, \& Cuadrado-Ballesteros, 2013).

In Taiwan, Wang focused on his study on how firm characteristics influence the disclosure of sustainability reporting for Taiwan 50 Index-listed companies. He considered disclosure of sustainability reporting as the dependent variable, and the firm's characteristics, including corporate governance and business characteristics as independent variables. Wang addressed the gaps in the literature on firm characteristics and the disclosure of sustainability reporting. He concluded that seven corporate governance and business characteristics are positively related to the disclosure of sustainability reporting.

These characteristics are the size of the board of directors, the ratio of independent directors, audit committee, the ratio of export income, percentage of foreign shareholders' holdings, Fixed asset staleness, and Firm growth. Whereas the percentage of director holdings and stock price per share is negatively related to the disclosure of sustainability reporting. The study supported the notion that stakeholder involvement is related to the disclosure of sustainability reporting (Wang, 2017). 
Current Trends within Sustainability Accounting Research: ...

Prof. Hamdy Mahmoud Kadous \& Dr. Heba Shaker Fathy Elbably

\section{Studies related to the quality of the existing frameworks or guidelines:}

In 2012 Leszczynska aimed to evaluate the content of sustainability reports published by international companies, determine the new trends in reporting, and assess the extent to which sustainability reporting can contribute to shareholder value by evaluating their usefulness for shareholders. Leszczynska analyzed the sustainability reports prepared in the period between 2005 and 2010. The results showed an evolution in the quality of sustainability reports and an increase in considering reporting in the fundamental fields, i.e., economic, environmental, and social. He also highly evaluated clarity and timeliness. However, critical gaps were identified in respect of inclusiveness, the relevance of information, and neutrality as shareholders found the general usefulness of sustainability reports insufficient (Leszczynska, 2012).

In their study, Bradford et al. explored the interest of customers as they represent one of the primary stakeholder groups towards the information being reported by companies following the Global Reporting Initiative (GRI) Corporate Sustainability framework.

The researchers conducted a factor analysis on stakeholder evaluation of the importance of CS activities by comparing the content of Corporate Sustainability reports to results from a 
Current Trends within Sustainability Accounting Research: ...

Prof. Hamdy Mahmoud Kadous \& Dr. Heba Shaker Fathy Elbably

large-scale consumer stakeholder survey. The study outcomes reflected that risk and compliance are dimensions of interest to customers, while the GRI economic dimension is not viewed as necessary. Furthermore, the study stated that social justice is the most important to consumer stakeholders. Moreover, it highlights the most significant specific activities within each factor to the consumer stakeholder group. Overall, researchers' findings contributed to CSR literature in accounting by revealing the impacts of the contingent nature of how and to what extent CSR performance on investors' beliefs about the firm value and the bids they expect to make in equity markets (Bradford, Earp, Showalter, \&Williams, 2017).

In 2018, Cantele et al. developed a new approach for assessing the quality of disclosure in sustainability reports published by water utility companies. They used a novel evaluation framework based on a scoring technique and an empirical analysis of the sustainability reports of Italian water utilities. The researchers highlighted the sustainability indicators suggested by the Global Reporting Initiative (GRI), and Sustainability Accounting Standard Board (SASB) have a low level of disclosure. Furthermore, most companies tend to disclose only qualitative information and neglect some material aspects of water management, such as water recycled, water sources, network resilience, and effluent quality. 
Current Trends within Sustainability Accounting Research: ...

Prof. Hamdy Mahmoud Kadous \& Dr. Heba Shaker Fathy Elbably

The study revealed that sustainability reporting is mainly viewed as a communication tool rather than a performance measurement and an accountability tool. Though, Cantele el al. suggested the need for a new and international industry-specific sustainability reporting standard (Cantele, Tsalis, \& Nikolaou, 2018).

\section{Studies related to Corporate Social Responsibility (CSR):}

In 2011, Hussainey et al. carried out a study to determine the factors affecting corporate social responsibility disclosure in Egypt. They examined the determinants of individual and aggregated types of CSR information depending on a sample of 111 Egyptian listed companies for the period of 2005-2010. The results of the study revealed that $66 \%$ of the Egyptian listed companies disclose, on average, 10-50 CSR statements. Also, product/customer information is used extensively by Egyptian listed companies compared with other types of CSR information. Finally, profitability is the fundamental determinant for the aggregated and most individual CSR information in Egypt (Hussainey, Elsayed, \& Razik, 2011).

As Accounting Review is the top journal in accounting, Dhaliwal and others conducted a joint paper in 2011 to investigate the rationale behind CSR voluntary disclosures and the benefits of disclosing standalone CSR reports. Their primary variable of interest is the cost of capital. The study applied to a sample of US 
Current Trends within Sustainability Accounting Research: ...

Prof. Hamdy Mahmoud Kadous \& Dr. Heba Shaker Fathy Elbably

public firms. Panel data analysis of the association between the probability to initiate CSR reporting and the cost of capital, and between changes in the cost of capital and the initiation of CSR disclosures.

The study concluded that firms with a high cost of capital in the preceding year mange to disclose their CSR activities in the current year. Furthermore, firms starting with superior CSR performance enjoy a subsequent decrease in the cost of capital, attract dedicated institutional investors and analyst coverage, and are more likely to raise equity capital following the initiations (Dhaliwal, Li, Tsang, \& Yang, 2011).

Complementing his efforts, Dhaliwal cooperated with Radhakrishnan, Tsang, \& Yang in developing another paper to explore the relationship between CSR disclosure and analysts' earnings forecast accuracy and identify the institutional settings in which CSR disclosures are further informative. The authors used analysts' earnings forecast accuracy and analysts' absolute earnings forecast error as the main variables. The study took place on an international level, 1297 public firms, 31 countries. Panel data analysis of the association between earnings forecast accuracy and the likelihood of issuing a CSR report is used. Dhaliwal et al. concluded that the issuance of standalone CSR reports is associated with higher analysts' forecast accuracy. Also, CSR disclosures contain information about future financial 
Current Trends within Sustainability Accounting Research: ...

Prof. Hamdy Mahmoud Kadous \& Dr. Heba Shaker Fathy Elbably

performance and accelerate the incorporation of future earnings information into the current stock price. The relation between CSR reporting and analysts' forecast accuracy is more robust for more stakeholder-oriented countries and firms and countries with more opaque financial disclosure (Dhaliwal, Radhakrishnan, Tsang, \& Yang, 2012).

As part of the ongoing efforts to support the significance of CSR, Kim and others published a paper in the Journal of Accounting Review to examine the earnings quality associated with CSR. The researchers' primary goal is to investigate whether socially responsible firms behave differently from other firms in their financial reporting. The study applied to 160 firms in the US. Panel data analysis of the association between earnings quality and the net score of CSR rating is used. Kim, Park, and Wier found that socially responsible firms are less likely to manage earnings through discretionary accruals, to manipulate real operating activities, and to be subject to SEC investigations. The study suggested that ethical concerns are likely to drive managers to produce high-quality financial reports (Kim, Park, \& Wier, 2012).

As a succession of the efforts of the accounting review journal in the field of Corporate Social Responsibility, Elliott et al. sought to find an answer for whether investors depend on their affective reactions to CSR performance in estimating fundamental value. 
Current Trends within Sustainability Accounting Research: ...

Prof. Hamdy Mahmoud Kadous \& Dr. Heba Shaker Fathy Elbably

The investors' estimates of fundamental value represent the primary variable of the study. The researchers found that investors unintentionally use affect generated by positive (negative) CSR performance to increase (decrease) their estimates of firms' fundamental value. This effect decreases when they are prompted to assess CSR performance explicitly (Elliott, Jackson, Peecher, \& White, 2014).

Huang \& Watson carried out one of the most significant studies to review four parts, which are determinants of CSR; the relation between CSR and financial performance, consequences of CSR; and the roles of CSR disclosure and assurance. Huang \& Watson summarized the accounting literature in these areas and commented on how accounting researchers discussed these specific issues. They found that, first, accounting researchers are experts in analyzing financial performance, which helps deepen the understanding of the CSR-financial performance relation. Second, accounting researchers have expertise in measuring cost behavior, which can help them uncover insights into CSR-related expenditures and the motivation for CSR-related activities. Third, accounting researchers are familiar with disclosure research, which has gained importance as firms seek to spread information about their CSR activities. Finally, accounting researchers have experience with assurance, which is critical as an assurance of CSR-related reporting gains popularity, and in many cases, 
Current Trends within Sustainability Accounting Research: ...

Prof. Hamdy Mahmoud Kadous \& Dr. Heba Shaker Fathy Elbably

becomes standardized. These are all vital areas of the future of CSR research (Huang \& Watson, 2015).

In 2018, Chung and Cho offered insights into the current state of Social and Environmental Accounting Research (SEA). They investigated the relations between corporate social performance (CSP), corporate social disclosure (CSD), and corporate financial performance (CFP) through the current state of scholarly work. They found that (SEA) has more opportunities for growth. They contributed to the literature through identifying new sustainability performance measurements and databases outside of the traditional realm, investigating emerging economies, and further examinations of less explored subtopic areas, such as taxation and merger and acquisition (M\&A), small and medium enterprises that can be some of the ways to move forward. Also, they suggested the significance of involving various stakeholder groups in the research initiatives to address some of the less comfortable but perhaps unavoidable areas of political conflicts (Chung, and Cho, 2018).

Shakkour and others conducted a study with a primary aim to identify how environmental or green Accounting could contribute to and ensure sustainable development. The results indicated that most organizations often ignore substantial environmental costs. Finally, the summary of the overall results of the review shows that the useful practice of environmental 
Current Trends within Sustainability Accounting Research: ...

Prof. Hamdy Mahmoud Kadous \& Dr. Heba Shaker Fathy Elbably

accounting is vital for sustainability development, especially for focusing on environmental and environmental taxes, costs, and appreciation of ecosystem services, the cost of carbon dioxide, and the cost of water pollution which ensure the sustainable development (Shakkour, Alaodat, Alqisi, and Alghazawi, 2018).

Brooks, \& Oikonomou investigated the effect of environmental, social, and governance disclosures and performance on firm value. They carried on a survey of the literature on the relation between CSR and firm-level financial performance in terms of accounting measures and stock market performance on the research concerning the performance of socially responsible investments. They found that there is a positive, statistically significant, albeit economically modest association between CSR and financial performance at the firm level. In contrast, a small minority of empirical work finds a negative relationship between the two concepts (Brooks \& Oikonomou, 2018).

\section{Assessing and Evaluating the previous studies:}

\subsection{Evaluating Studies directly related to Sustainability accounting and its consequences:}

Sustainability accounting and reporting can have many economic consequences that cannot be enumerated. Most empirical studies concerning sustainability accounting or reporting are 
Current Trends within Sustainability Accounting Research: ...

Prof. Hamdy Mahmoud Kadous \& Dr. Heba Shaker Fathy Elbably

emphasizing on the developed countries while others were biased toward oil and gas firms.

Many studies used financial performance as a subjective measure of how well a firm can use its assets to generate resources to understand and measure the effect of sustainability accounting on the firm's financial performance.

Among the theories about sustainability reporting, the dominant ones are the agency, legitimacy, stakeholder, and signaling theories. The researcher supports scholars that use Stakeholder theory in addressing sustainability issues as it assumes that a business organization needs to maintain good relations with all stakeholders, rather than merely with its shareholders, and must satisfy their informational needs through sustainability reports (Reverte, 2009; Lourenço and Branco, 2013).

Disclosing sustainability-related issues to stakeholders enhances the accountability and transparency of the entity's operations, which assist investors in making proper evaluations. Moreover, sustainability reporting provides additional benefits such as enhancing entity image, strengthening community relations, and legitimating firm activities (Kuzey \& Uyar, 2017). Additionally, a primary effect of corporate sustainability disclosure is to mitigate information asymmetries between the firm and its investors and among more and less-informed investors. 
Current Trends within Sustainability Accounting Research: ...

Prof. Hamdy Mahmoud Kadous \& Dr. Heba Shaker Fathy Elbably

The literature shows an overwhelmingly positive relationship between sustainability practices and the market value of equity and return on investment. Moreover, Almaleeh found that there is a positive relationship between the degree of firms' sustainability and cash dividends paid to its stockholders by investigating Egyptian companies (Almaleeh, 2019).

As a result of the academic research concentration on sustainability accounting and its consequences, the business environment has increasingly begun to focus on pathways to long-term, sustainable growth. Likewise, there is increased awareness of the effect of environmental, social, and governance (ESG) issues on the financial outcomes. Although they are not inherently economic, ESG factors can reflect business issues that have measurable impacts on the company's statement of financial position, its income statement, or its risk profile, and thus its cost of capital.

As an implicit conclusion from previous studies, the accounting profession's role is essential to incorporate sustainability factors into enterprise risk management processes to bridge the gap between accounting and risk management. 
Current Trends within Sustainability Accounting Research: ...

Prof. Hamdy Mahmoud Kadous \& Dr. Heba Shaker Fathy Elbably

\subsection{Evaluating the Studies related to Sustainability accounting and its determinants:}

Most of the prior studies found that there is a significant positive relationship between firm size and sustainability reporting, as well as between firm size and assurance statements (Kuzey \& Uyer, 2017).

Some scholars suggest a strong industry influence on sustainability reporting (Skouloudis et al., 2014). Liu and Anbumozhi (2009) argue that environment-sensitive industries are inclined to disclose environmental issues since they are likely to harm the environment, and as such, are inclined to stricter regulation. Legendre and Coderre (2013) also point out that firms operating in high-risk industries are more inclined to publish high-quality sustainability information under pressure from their stakeholders. Prior studies have provided evidence that industry affiliation has a significant impact on sustainability reporting (Brammer and Pavelin, 2008; Reverte, 2009; Kansal et al., 2014; Shamil et al., 2014), although there are exceptions (Nazari et al., 2015). Furthermore, Legendre and Coderre (2013) and Branco et al. (2014) proved that GRI application level and independent assurance, respectively, are positively associated with industry affiliation.

Consequently, media exposure and stakeholder pressure as external determinants are also consistently found to have a 
Current Trends within Sustainability Accounting Research: ...

Prof. Hamdy Mahmoud Kadous \& Dr. Heba Shaker Fathy Elbably

positive influence on sustainability reporting because the size variable can be considered to be linked with corporate visibility. Overall, research displays a bias toward variables related to a company's size and economic and financial performance. Also, other factors such as capital intensity, a company's listing on the stock market, government ownership, and foreign ownership have been examined in prior studies. They have a positive effect on sustainability reporting. On the other hand, a company's systematic risk and concentrated ownership structure seem to impede sustainability reporting. Furthermore, research tends to deny a significant effect of a company's market-to-book value, financing activities on the capital market, and age of fixed assets. Finally, researchers provide somewhat inconsistent and ambiguous findings regarding profitability and indebtedness.

\subsection{Evaluating Studies related to GRI and different frameworks:}

There is a lack of research, especially regarding the quality of reporting. Some studies measured CSR information disclosure by the level of standardized information in terms of the Global Reporting Initiative (GRI) guidelines. Previous studies have used simple measures such as word count, sentence count, and page count of CSR reports, but this approach may not reflect differences in the content (Chen and Bouvain, 2009). In 
Current Trends within Sustainability Accounting Research: ...

Prof. Hamdy Mahmoud Kadous \& Dr. Heba Shaker Fathy Elbably

response, some recent studies have used international indicators such as the GRI guidelines.

Some studies inferred that Implementation of the GRI (G4) Guidelines 'Principles for Defining Report Content', (precisely Materiality Principle) would result in more diversity in practice, thereby further complicating the comparability concern (Bradford et al., 2016). Recent literature moved from studying the impact of single sustainability dimensions on corporate financial performance towards a more encompassing total sustainability impact (Alshehhi, 2018).

\subsection{Evaluating Studies related to Corporate Social Responsibility (CSR):}

Academic literature has proposed a high number of definitions for the term Corporate Social Responsibility during the last decades. In general terms, these are not contradictory but evolutionary, as the definition of the concept is taking shape with the contribution of different authors (Carroll, 1999). As a result, nowadays, CSR encompasses various theories, approaches, and terminology (Garriga and Melé, 2004).

Some studies examined the relationship between corporate social responsibility and financial performance by using different variables such as return on assets and return on equity, community performance, employee relation, and environmental 
Current Trends within Sustainability Accounting Research: ...

Prof. Hamdy Mahmoud Kadous \& Dr. Heba Shaker Fathy Elbably

management system. Some researchers like Olayinka and Temitope found that CSR has a positive and significant relationship with financial performance measures (Olayinka and Temitope, 2011). Others found that accounting researchers can provide insights into many CSR issues because they are experts in many areas that directly apply to CSR research.

CSR is emphasizing mostly on the social element of sustainability and ignoring both environmental and economic dimensions. Therefore, a vast number of theoretical researches in the literature are trying to establish a global definition for corporate sustainability that considers the three competing dimensions of sustainability (Alshehhi, 2018).

Therefore, the researcher sees that sustainability reporting is broader that the corporate social responsibility concept as it consolidates various dimensions of sustainability in one report.

\section{General evaluation:}

From this extensive literature, the researcher sees that more and better sustainability disclosures can improve financial reporting quality through tangible capital-market benefits in the form of improved liquidity, lower cost of capital, higher asset prices (or firm value), and potentially even better corporate decisions.

Moreover, Sustainability reports provide a different type of information than financial reports. They indicate the capability of 
Current Trends within Sustainability Accounting Research: ...

Prof. Hamdy Mahmoud Kadous \& Dr. Heba Shaker Fathy Elbably

a firm's long-term value creation by considering its economic, social, and environmental performance.

Prior studies have mostly focused on developed countries or a global scale such as the U.S., Canada (Berthelot et al., 2012), and Australia (Bachoo et al., 2013). A limited number of existing studies regarding the value-enhancing role of sustainability reporting have been carried out in emerging markets. It might not be reasonable to generalize the findings of these studies for emerging countries, as their underlying legal or institutional background differs from those in developed countries.

For example, developing countries have wider gaps in enforcement in terms of environmental protection laws or human rights compared to developed countries. Moreover, stakeholders (i.e., civil organizations, media, consumers, activists) influence in emerging countries might be less influential than in developed ones.

Studies from developing countries stay rare. More research is needed to promote an understanding of the relationship between sustainable corporate practices and financial performance.

Focusing on Egypt as an emerging economy, sustainability accounting, and reporting is increasingly recognized as a serious concern. A considerable number of Egyptian companies disclose their environmental and social activities. In addition to that, The 
Current Trends within Sustainability Accounting Research: ...

Prof. Hamdy Mahmoud Kadous \& Dr. Heba Shaker Fathy Elbably

Egyptian Exchange (EGX) launched its S\&P EGX ESG index in March 2010; the first \& only ESG index in the Middle East and North Africa Region designed to track the performance of companies listed on EGX that demonstrate leadership in environmental, social and corporate governance (ESG) issues. This index aims to raise the profile of those companies that perform well in the areas of environmental, social, and corporate governance responsibility when compared to their market peers (EGX, 2016).

Although these efforts, the researcher found that there is a gap in researches that address the impact of sustainability accounting and reporting on financial reporting quality in Egypt. Additionally, the absence of a unified framework or guidelines that can be adopted on Egypt. on the practical side, it is voluntary to prepare sustainability reports, and even companies that prepare it do not follow the same guidelines which has drawn the researcher's attention to the question of this study; Does the absence of a unified framework for sustainability accounting affect financial reporting quality?

Finally, the researcher noticed that the number of publications from countries with developed economies is insignificant compared to those of developing economies. A gap in the literature exists for publications that examine the subject of corporate sustainability impact on financial performance in 
Current Trends within Sustainability Accounting Research: ...

Prof. Hamdy Mahmoud Kadous \& Dr. Heba Shaker Fathy Elbably

countries of developing economies. Further research is needed for countries of developing economies.

\section{Conclusion:}

The notion of Sustainability Accounting (SA) rapidly became popular and has been explored rigorously by the academic community. This paper examined current trends in Sustainability accounting research from existing bodies of literature in accounting and other relevant disciplines of (SA) research. SA started to gain publicity in some of the most cited accounting journals in the recent few years due to the increasing demand for $\mathrm{SA}$ research.

This article does not claim to have covered the SA literature in its entirety, but aimed at presenting a broader scope in the journals reviewed. The study found that SA has more opportunities for positive growth. Identifying new sustainability performance measurements and databases outside of the traditional realm, investigating emerging economies, and further examinations of less explored subtopic areas can be some of the ways to move forward. Also, there are suggestions made to involve various stakeholder groups in the research initiatives and engage them to address some of the less comfortable but perhaps unavoidable areas of political conflicts. The Sustainability accounting literature will continue to proliferate and remain lucrative for 
Current Trends within Sustainability Accounting Research: ...

Prof. Hamdy Mahmoud Kadous \& Dr. Heba Shaker Fathy Elbably

current and future researchers, but not without persistent effort for improvements and development.

\section{References:}

Aboud, A., \& Diab, A. (2018). The impact of social, environmental, and corporate governance disclosures on firm value. Journal of Accounting in Emerging Economies, 8(4), 442-458. DOI: 10.1108/jaee-08-2017-0079

Almaleeh, N. M. (2019). Are Sustainable Firms More Profitable? Evidence From Egypt. International Journal of Accounting and Financial Reporting, 9(1), 122. DOI: 10.5296/ijafr. v9i1.13984

Alshehhi, A., Nobanee, H., \& Khare, N. (2018). The Impact of Sustainability Practices on Corporate Financial Performance: Literature Trends and Future Research Potential. Sustainability, 10(2), 494. DOI: 10.3390/su10020494

Bradford, M., Earp, J. B., Showalter, D. S., \& Williams, P. F. (2017). Corporate Sustainability Reporting and Stakeholder Concerns: Is There a Disconnect? Accounting Horizons, 31(1), 83-102. DOI: 10.2308/acch-51639

Brooks, C., \& Oikonomou, I. (2018). The effects of environmental, social, and governance disclosures and performance on firm value: A review of the literature in accounting and finance. The British Accounting Review, 50(1), 1-15. DOI: 10.1016/j.bar.2017.11.005

Burritt, R. L., \& Schaltegger, S. (2010). Sustainability accounting and reporting: fad or trend? Accounting, Auditing \& Accountability Journal, 23(7), 829-846. DOI: 10.1108/09513571011080144

Cantele, S., Tsalis, T., \& Nikolaou, I. (2018). A New Framework for Assessing the Sustainability Reporting Disclosure of Water Utilities. Sustainability, 10(2), 433. DOI: 10.3390/su10020433 
Current Trends within Sustainability Accounting Research: ...

Prof. Hamdy Mahmoud Kadous \& Dr. Heba Shaker Fathy Elbably

Chung, J., \& Cho, C. H. (2018). Current Trends within Social and Environmental Accounting Research: A Literature Review. Accounting Perspectives, 17(2), 207-239. DOI: 10.1111/1911-3838.12171

Cohen, J. R., Holder-Webb, L. L., Nath, L., \& Wood, D. (2012). Corporate Reporting of Nonfinancial Leading Indicators of Economic Performance and Sustainability. Accounting Horizons, 26(1), 65-90. DOI: $10.2308 /$ acch-50073

Dhaliwal, D. S., Li, O. Z., Tsang, A., \& Yang, Y. G. (2011). Voluntary Nonfinancial Disclosure and the Cost of Equity Capital: The Initiation of Corporate Social Responsibility Reporting. The Accounting Review, 86(1), 59-100. DOI: 10.2308/accr.00000005

Dhaliwal, D. S., Radhakrishnan, S., Tsang, A., \& Yang, Y. G. (2012). Nonfinancial Disclosure and Analyst Forecast Accuracy: International Evidence on Corporate Social Responsibility Disclosure. The Accounting Review, 87(3), 723-759. DOI: 10.2308/accr-10218

Elliott, W. B., Jackson, K. E., Peecher, M. E., \& White, B. J. (2014). The Unintended Effect of Corporate Social Responsibility Performance on Investors Estimates of Fundamental Value. The Accounting Review, 89(1), 275-302. DOI: 10.2308/accr-50577

Huang, X. "B., \& Watson, L. (2015). Corporate social responsibility research in accounting. Journal of Accounting Literature, 34, 1-16. DOI: 10.1016/j.acclit.2015.03.001

Hussainey, K., Elsayed, M., \& Razik, M. A. (2011). Factors Affecting Corporate Social Responsibility Disclosure in Egypt. Corporate Ownership and Control, 8(4). DOI: 10.22495/cocv8i4c4art5 
Current Trends within Sustainability Accounting Research: ...

Prof. Hamdy Mahmoud Kadous \& Dr. Heba Shaker Fathy Elbably

Ienciu, I.-A., Popa, I. E., \& Ienciu, N. M. (2012). Environmental Reporting and Good Practice of Corporate Governance: Petroleum Industry Case Study. Procedia Economics and Finance, 3, 961-967. DOI: 10.1016/s2212-5671(12)00258-4

Kaur, A., \& Lodhia, S. (2018). Stakeholder engagement in sustainability, accounting, and reporting. Accounting, Auditing \& Accountability Journal, 31(1), 338-368. DOI: 10.1108/aaaj-12-2014-1901

Khan, M., Serafeim, G., \& Yoon, A. (2016). Corporate Sustainability: First Evidence on Materiality. The Accounting Review, 91(6), 1697-1724. DOI: $10.2308 /$ accr-51383

Kim, Y., Park, M. S. \& Wier, B. (2012). Is Earnings Quality Associated with Corporate Social Responsibility? The Accounting Review, 87(3), 761-796. DOI: 10.2308/accr-10209

Kuzey, C., \& Uyar, A. (2017). Determinants of sustainability reporting and its impact on firm value: Evidence from the emerging market of Turkey. Journal of Cleaner Production, 143, 27-39. DOI: 10.1016/j.jclepro.2016.12.153

Leszczynska, A. (2012). Towards shareholders value: an analysis of sustainability reports. Industrial Management \& Data Systems, 112(6), 911-928. DOI: 10.1108/02635571211238518

Lodhia, S., \& Hess, N. (2014). Sustainability accounting and reporting in the mining industry: current literature and directions for future research. Journal of Cleaner Production, 84, 43-50. DOI: 10.1016/j.jclepro.2014.08.094

Loh, L., Thomas, T., \& Wang, Y. (2017). Sustainability Reporting and Firm Value: Evidence from Singapore-listed Companies. Sustainability, 9(11), 2112. DOI: 10.3390/su9112112 
Current Trends within Sustainability Accounting Research: ...

Prof. Hamdy Mahmoud Kadous \& Dr. Heba Shaker Fathy Elbably

Martínez-Ferrero, J., Garcia-Sanchez, I. M., \& Cuadrado-Ballesteros, B. (2013). Effect of Financial Reporting Quality on Sustainability Information Disclosure. Corporate Social Responsibility and Environmental Management, 22(1), 45-64. DOI: 10.1002/csr.1330

Nnamani, J. N., Onyekwelu, U. L., \& Ugwu, O. K. (2017). Effect of sustainability accounting and reporting on financial performance of firms in Nigeria brewery sector. European Journal of Business and Innovation Research, 5(1), 1-15.

Passetti, E., Cinquini, L., Marelli, A., \& Tenucci, A. (2014). Sustainability accounting in action: Lights and shadows in the Italian context. The British Accounting Review, 46(3), 295-308. DOI: 10.1016/j.bar.2014.05.002

Qiu, Y., Shaukat, A., \& Tharyan, R. (2016). Environmental and social disclosures: Link with corporate financial performance. The British Accounting Review, 48(1), 102-116. DOI: 10.1016/j.bar.2014.10.007

Schaltegger, S., \& Burritt, R. L. (2010). Sustainability accounting for companies: Catchphrase or decision support for business leaders? Journal of World Business, 45(4), 375-384. DOI: 10.1016/j.jwb.2009.08.002

Schaltegger, S., \& Zvezdov, D. (2015). Gatekeepers of sustainability information: exploring the roles of accountants. Journal of Accounting \& Organizational Change, 11(3), 333-361. DOI: 10.1108/jaoc-102013-0083

Shakkour, A., Alaodat, H., Alqisi, E., \& Alghazawi, A. (2018). The role of environmental accounting in sustainable development empirical study. Journal of Applied Finance and Banking, 8(1), 71-87. 
Current Trends within Sustainability Accounting Research: ...

Prof. Hamdy Mahmoud Kadous \& Dr. Heba Shaker Fathy Elbably

Sutopo, B., Kot, S., Adiati, A., \& Ardila, L. (2018). Sustainability Reporting and Value Relevance of Financial Statements. Sustainability, 10(3), 678. DOI: $10.3390 /$ su10030678

Wang, M.-C. (2017). The Relationship between Firm Characteristics and the Disclosure of Sustainability Reporting. Sustainability, 9(4), 624. DOI: 10.3390/su9040624 